\title{
Leaching Behavior of Lead Contaminated Soil Sample by Using Sugarcane Bagasse in Stabilization/Solidification Method
}

\author{
Mohamad Azim Mohammad Azmi ${ }^{1, a^{*}}$, Saiful Azhar Ahmad Tajudin ${ }^{2, b}$ \\ and Aeslina Abdul Kadir ${ }^{3}$, Mohamed Nur Shafiq Mohamed Hanif ${ }^{4}$, \\ Nurul Syakeera Nordin ${ }^{5}$, Mohd Shalahuddin Adnan ${ }^{6}$
}

\author{
${ }^{1,2,3,4,5,6}$ Faculty of Civil and Environmental Engineering, Universiti Tun Hussein Onn Malaysia \\ amohamadazimazmi@gmail.com, bsaifulaz@uthm.edu.my
}

\begin{abstract}
Keywords: Stabilization/Solidification; Lead; Sugarcane Bagasse; Toxicity Characteristics Leaching Procedure; Synthetic Precipitation Leaching Procedure
\end{abstract}

\begin{abstract}
Recently, Stabilization/Solidification (S/S) method has been focusing on the usage of agricultural waste as an alternative towards environmental friendly and low cost material to substitute cement. The aim of this study is to determine the leachability of lead contaminated soil by using sugarcane bagasse as partial replacement of cement in S/S method. In this study, different percentages $(2.5 \%, 5 \%$ and $7.5 \%)$ of treated and untreated sugarcane bagasse have been utilized as a partial replacement to cement. Toxicity Characteristic Leaching Procedure (TCLP) and Synthetic Precipitation Leaching Procedure (SPLP) have been conducted to determine the leachability of lead contaminated soil. The results indicate that with $7.5 \%$ of treated sugarcane bagasse replacement in cement resulted significant reduction of lead contaminant in soil up to $99 \%$ after 28 days. As a conclusion, treated sugarcane bagasse could be an alternative low cost material in the S/S method as it can significantly reduce the remediation cost normally incurred by the usage of cement.
\end{abstract}

\section{Introduction}

Stabilization/Solidification $(\mathrm{S} / \mathrm{S})$ is an established technique used for treating industrial waste sludge prior to proper landfill disposal. This technique has been widely applied to immobilize heavy metal in contaminated soils, sediments, and sludge with additives such as cement, lime and fly ash. Recent year, as a result of the high energy consumption in the cement manufactured and the environmental damage caused by the discharge of high amounts of greenhouse gases during its production, the cement industry has been leveled out as one of the major contributors of anthropogenic $\mathrm{CO}_{2}$ emissions with about 5\% globally [1]. At the point of view, several researches have been directed towards partial or total substitution of Portland cement with agricultural waste which is typically free of charge [2]. Therefore, the utilization of this material in making cementbonded materials offers an attractive alternative to their disposal. For this purpose, lignocellulose such as sugarcane bagasse and others deliver a number of desirable features including low density, low requirements of processing equipment, negligible abrasion to the processing machinery and abundant new material availability [3]. Furthermore, this material can be effectively encapsulated in a cementitious matrix as it is known that plant based fibers have been applied with considerable success with inorganic binders like ordinary Portland cement (OPC).

Nevertheless, with the usage of agricultural waste in replacing cement, it is significant to investigate the environmental impact of $\mathrm{S} / \mathrm{S}$ materials towards the environment interms of the pollutions lechability [4]. The leaching data collected through laboratory leaching tests could estimate and simulate the behavior of waste under ideal, static or worst case field condition. Therefore, the objective of this study was to determine the leachability of lead contaminated soil by using sugarcane bagasse as partial replacement of cement in S/S method. 


\section{Materials and methods}

Presently, Toxicity Characteristic Leaching Procedure (TCLP) and Synthetic Precipitation Leaching Procedure (SPLP) have been used to evaluate the effectiveness of stabilization/solidification remediation technique

Contaminated soil and binder system Clay soil sample was collected at a location near to the Research Center for Soft Soil (RECESS), University Tun Hussein Onn Malaysia (UTHM). The top of the soil to a depth of 3 meters has been withdrawn in order to avoid taking the humus and plant sources. The soil sample was oven-dried at $105^{\circ} \mathrm{C}$ for 24 hours. Dried soil was crushed to the fine powders prior to storage in a polyethylene plastic bag. The initial concentration of $\mathrm{Pb}$ is $500 \mathrm{ppm}$. The selection of this concentration would be to test the worst case of lead toxicity in soil ranging $500-1500 \mathrm{ppm}$ that are harmful to humans and animals health [5]. Treatment of the lead contaminated soil was conducted using Type II ordinary Portland cement (OPC) as the main binder and supplemented by treated and untreated sugarcane bagasse (SCB). The SCB was collected from the hawker around Parit Raja, Johor and divided into two parts, the first part is untreated and the second part is treated. The untreated SCB is raw as collected but the treated SCB was exposed under acidic condition to eliminate the possibility of the cellulose fibers and to liberate the lignin. For the treated part, the SCB was boiled with $0.1 \mathrm{M} \mathrm{HCl}$ for approximately $45 \mathrm{~min}$, with the residue was washed free of sugars and hydrolysis products. This procedure was repeated 3 to 4 times until the filtrate was virtually colorless [8]. Both type of SCB were dried in the oven under a temperature of $105^{\circ} \mathrm{C}$ for 24 hours in order to eliminate the moisture content, then finally were grinded into $90 \mu \mathrm{m}$ of particles size.

Production of $\mathbf{S} / \mathbf{S}$ products The binder (OPC with untreated and treated sugarcane bagasse) was added to the contaminated soil at binder-to-dry soil $\left(\mathrm{B} / \mathrm{S}_{\mathrm{d}}\right)(\mathrm{w} / \mathrm{w} \%)$ ratio. Table 1 summarize the mix design of the study. A control mixture consisting of $100 \%$ OPC was also included as part of the mix design. Mixing of these materials were added with deionized water $(<1 \mu \mathrm{s} / \mathrm{cm})$ at water -to-mixture (W/M) ratio, ranging from $40 \%$ to $50 \%$ dry weight. The mixtures were cast into cylindrical moulds, $38 \mathrm{~mm}$ diameter and $76 \mathrm{~mm}$ high, to the same compaction density in three layer and cured at a controlled condition (temperature $=25 \pm 2{ }^{\circ} \mathrm{C}$, humidity $>70 \%$ )

\begin{tabular}{|c|c|c|c|}
\hline Mixing Type & Sample & Percentage of Binder & $\begin{array}{c}\text { Total Weight of } \\
\text { Sample }(\mathrm{g})\end{array}$ \\
\hline $\begin{array}{c}(\mathrm{Clay}+\mathrm{Pb})+\mathrm{OPC} \\
\quad(\text { control })\end{array}$ & $\begin{array}{l}\mathrm{A} \\
\mathrm{B} \\
\mathrm{C}\end{array}$ & $\begin{array}{l}5 \% \mathrm{OPC} \\
10 \% \mathrm{OPC} \\
15 \% \mathrm{OPC} \\
\end{array}$ & $\begin{array}{l}160 \\
160 \\
160 \\
\end{array}$ \\
\hline $\begin{array}{c}\text { (Clay }+\mathrm{Pb})+\mathrm{OPC}+ \\
\text { SCB (untreated) }\end{array}$ & $\begin{array}{l}\mathrm{D} \\
\mathrm{E} \\
\mathrm{F}\end{array}$ & $\begin{array}{c}2.5 \% \mathrm{OPC} 2.5 \% \mathrm{SCB} \\
5 \% \mathrm{OPC} \% \mathrm{SCB} \\
7.5 \% \mathrm{OPC} 7.5 \% \mathrm{SCB} \\
\end{array}$ & $\begin{array}{l}160 \\
160 \\
160 \\
\end{array}$ \\
\hline $\begin{array}{c}(\mathrm{Clay}+\mathrm{Pb})+\mathrm{OPC}+ \\
\text { SCB (treated) }\end{array}$ & $\begin{array}{l}\mathrm{G} \\
\mathrm{H} \\
\mathrm{I}\end{array}$ & $\begin{array}{c}2.5 \% \text { OPC } 2.5 \% \mathrm{SCB} \\
5 \% \text { OPC } 5 \% \mathrm{SCB} \\
7.5 \% \text { OPC } 7.5 \% \mathrm{SCB}\end{array}$ & $\begin{array}{l}160 \\
160 \\
160\end{array}$ \\
\hline $\mathrm{Clay}+\mathrm{Pb}$ & $\mathrm{J}$ & - & 160 \\
\hline
\end{tabular}

Leaching Test Two tests methods were used to evaluate the leaching behavior of cement incorporated with treated and untreated SCB as a binder to remediate lead contaminated soil. Leaching test were carried out in accordance to the standard procedures prescribed by US EPA, TCLP method 1311[6] and SPLP method 1312 [7].

i. TCLP - This method was developed to simulate the leaching of constituents into ground water under conditions found in municipal solid waste (MSW) landfills. A 
volume of TCLP leachant No. $2(5.7 \mathrm{ml} / \mathrm{l}$ glacial acetic acid aqueous solution at $\mathrm{pH}$ 2.88) was added at a volume of 20 times the weight of the sample (20:1). The extraction period for the sample was 18 hour under rotary agitation at $30 \mathrm{rpm}$. Subsequently, the sample was filtered using Grade GF/F $0.7-\mu \mathrm{m}$ glass fibre filter paper and $\mathrm{pH}$ was measure at the end of the extraction. The sample was filtered within $2 \mathrm{~h}$ of the 18-h extraction period to ensure method reproducibility [9]. This procedure differs from the EPA TCLP [6] method in that one-tenth (1:10) of the amount of the sample was used. Apart from the modified step, all other aspect of the method remained the same.

ii. SPLP - This method was used to stimulates the effect of the acid rain on the contaminated soil. SPLP is very similar to the TCLP method 1311 but using different leachant solution. A mixture of diluted nitric acid and sulpharic acid ( $\mathrm{pH}$ of $4.20 \pm 0.05)$ were used. Concentrated sulfuric acid $(60 \mathrm{~g})$ was mixed with $40 \mathrm{~g}$ of concentrated nitric acid (60:40). Apart from the leachant solution, all the step was the same with the TCLP method.

After filtration, metal concentrations of the leachate was determined via Perkin-Elmer AA800 Atomic Absorption Spectrometer (AAS).

\section{Result and Discussion}

pH and Lead leachability (TCLP) Fig. 1 shows the pH and Lead leachability due to TCLP method. The $\mathrm{pH}$ values of leachate samples (A, B, C, E, F, G, H and I) are essentially alkaline at $7.11,9.43,12.04,7.28,9.76,8.12,11.78$ and 12.96 respectively while leachate $\mathrm{pH}$ of sample $\mathrm{D}$ and $\mathrm{J}$ are slightly acidic at 5.97 and 6.28 respectively. These values clearly indicate a trend which demonstrate that the increases of treated SCB by wt\% in the mix design decreases leachate $\mathrm{pH}$ of the sample.

Table 2 Percentage of Lead Reduction from TCLP Test

\begin{tabular}{|c|c|c|c|c|}
\hline \multirow[b]{2}{*}{ Sample } & \multirow[b]{2}{*}{ Sample mixing } & \multirow[b]{2}{*}{$\begin{array}{c}\text { Initial } \\
\text { concentration } \\
(\mathrm{mg} / \mathrm{L}) \text { of } \\
\text { Lead }\end{array}$} & \multicolumn{2}{|c|}{ After treatment } \\
\hline & & & $\begin{array}{c}\text { Lead } \\
\text { Concentration } \\
(\mathrm{mg} / \mathrm{L}) \\
\text { TCLP method }\end{array}$ & $\begin{array}{l}\text { Percentage of } \\
\text { Lead } \\
\text { reduction (\%) }\end{array}$ \\
\hline A & $5 \% \mathrm{OPC}$ & 500 & 36 & 92.80 \\
\hline B & $10 \% \mathrm{OPC}$ & 500 & 4.82 & 99.04 \\
\hline $\mathrm{C}$ & $15 \% \mathrm{OPC}$ & 500 & 3.10 & 99.38 \\
\hline D & $\begin{array}{l}2.5 \% \mathrm{OPC} 2.5 \% \mathrm{SCB} \\
\text { (UT) }\end{array}$ & 500 & 23 & 95.40 \\
\hline E & $\begin{array}{c}5 \% \mathrm{OPC} 5 \% \mathrm{SCB} \\
\text { (UT) }\end{array}$ & 500 & 3.73 & 99.25 \\
\hline F & $\begin{array}{c}7.5 \% \mathrm{OPC} 7.5 \% \mathrm{SCB} \\
\text { (UT) }\end{array}$ & 500 & 3.66 & 99.27 \\
\hline G & $\begin{array}{l}2.5 \% \mathrm{OPC} 2.5 \% \mathrm{SCB} \\
\text { (T) }\end{array}$ & 500 & 11 & 97.80 \\
\hline $\mathrm{H}$ & $5 \% \mathrm{OPC} 5 \% \mathrm{SCB}(\mathrm{T})$ & 500 & 2.89 & 99.42 \\
\hline I & $\begin{array}{l}7.5 \% \mathrm{OPC} 7.5 \% \mathrm{SCB} \\
(\mathrm{T})\end{array}$ & 500 & 2.11 & 99.58 \\
\hline $\mathrm{J}$ & $\begin{array}{l}7.5 \% \mathrm{OPC} 7.5 \% \mathrm{SCB} \\
\text { (T) }\end{array}$ & 500 & 93 & 81.40 \\
\hline
\end{tabular}

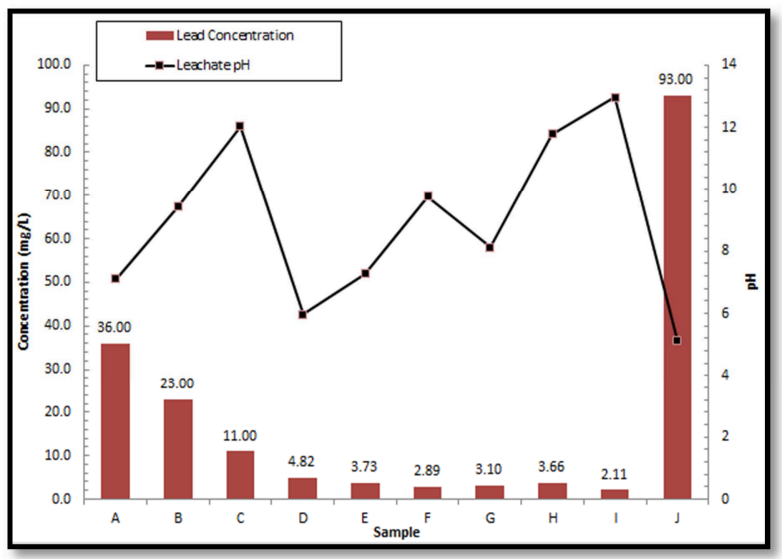

Fig. $1 \mathrm{pH}$ and Lead Leachability

Table 2 shows the lead-contaminated clay (sample J) has been leached out $81 \%$ of lead in 18 -h extraction. This indicated that, either lead has been absorbed by a clay surfaces or bound in the silicate and organic materials [9]. By adding 5\% of OPC, lead concentration was reduce up to $93 \%$ as the $\mathrm{pH}$ was increased from 5.12 to 7.11 . The highest reduction of lead concentration was occurred in a sample with additional of $7.5 \%$ OPC $+7.5 \%$ treated SCB which is $99.58 \%$ reduction with $\mathrm{pH} 5.12$ to 12.96 . The significant reduction occurred due to two main mechanisms which are microencapsulation process and chemical fixation [10].

It is shown in Fig. 1 that lead concentration for all sample with treated and untreated SCB are below the lead leachability limit of $5 \mathrm{mg} / \mathrm{L}$ stipulated by Kualiti Alam Sdn. Bhd [11]. This shows that the $\mathrm{S} / \mathrm{S}$ treatment of contaminated soil using treated and untreated SCB with OPC is successful. Increases of treated SCB in sample $\mathrm{G}, \mathrm{H}$ and I constitute major decreased of lead concentration. 
This shows that, with additional of treated SCB wt\% with OPC, lead is more easily leached out from the sample.

pH and lead leachability (SPLP) Fig. 2 shows the pH and lead lechability of SPLP leachate. The $\mathrm{pH}$ values of leachates of sample B, C, D, E, f, G, H and I are alkaline at 8.23, 12.64, 7.89, 9.91, $12.20,8.16,11.03$ and 13.04 respectively while leachate $\mathrm{pH}$ of sample $\mathrm{A}$ and $\mathrm{J}$ are slightly acidic at 6.97 and 6.63 respectively. The influence of $\mathrm{pH}$ that commonly precipitate lead range from 9 to 10 [12]. However, at a lower $\mathrm{pH}$, the precipitation will be higher as shown in Fig. 2 where the overall $\mathrm{pH}$ is between 6.7 to 13 and lead has been leached out up to $99 \%$. This suggests that precipitation may be the main mechanism in this study as lead leachability is proven to be very $\mathrm{pH}$ dependent [13].

Table 3 Percentage of Lead Reduction from SPLP Test

\begin{tabular}{|c|c|c|c|c|}
\hline \multirow[b]{2}{*}{ Sample } & \multirow[b]{2}{*}{ Sample mixing } & \multirow[b]{2}{*}{$\begin{array}{c}\text { Initial } \\
\text { concentration } \\
(\mathrm{mg} / \mathrm{L}) \text { of } \\
\text { Lead }\end{array}$} & \multicolumn{2}{|c|}{ After treatment } \\
\hline & & & $\begin{array}{c}\text { Lead } \\
\text { Concentration } \\
(\mathrm{mg} / \mathrm{L}) \\
\text { TCLP method } \\
\end{array}$ & $\begin{array}{l}\text { Percentage of } \\
\text { Lead } \\
\text { reduction (\%) }\end{array}$ \\
\hline A & $5 \% \mathrm{OPC}$ & 500 & 36 & 92.80 \\
\hline B & $10 \% \mathrm{OPC}$ & 500 & 4.82 & 99.04 \\
\hline $\mathrm{C}$ & $15 \% \mathrm{OPC}$ & 500 & 3.10 & 99.38 \\
\hline D & $\begin{array}{c}2.5 \% \mathrm{OPC} 2.5 \% \mathrm{SCB} \\
\text { (UT) }\end{array}$ & 500 & 23 & 95.40 \\
\hline E & $\begin{array}{c}5 \% \mathrm{OPC} 5 \% \mathrm{SCB} \\
\text { (UT) }\end{array}$ & 500 & 3.73 & 99.25 \\
\hline F & $\begin{array}{l}7.5 \% \text { OPC } 7.5 \% \mathrm{SCB} \\
\text { (UT) }\end{array}$ & 500 & 3.66 & 99.27 \\
\hline G & $\begin{array}{l}2.5 \% \mathrm{OPC} 2.5 \% \mathrm{SCB} \\
(\mathrm{T})\end{array}$ & 500 & 11 & 97.80 \\
\hline $\mathrm{H}$ & $5 \% \mathrm{OPC} 5 \% \mathrm{SCB}(\mathrm{T})$ & 500 & 2.89 & 99.42 \\
\hline I & $\begin{array}{l}7.5 \% \mathrm{OPC} 7.5 \% \mathrm{SCB} \\
\text { (T) }\end{array}$ & 500 & 2.11 & 99.58 \\
\hline $\mathrm{J}$ & $\begin{array}{l}7.5 \% \mathrm{OPC} 7.5 \% \mathrm{SCB} \\
\text { (T) }\end{array}$ & 500 & 93 & 81.40 \\
\hline
\end{tabular}

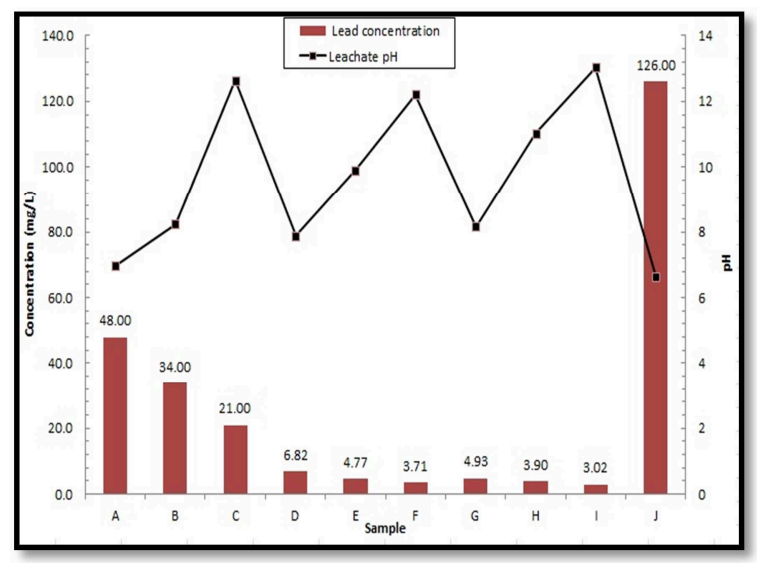

Fig. $2 \mathrm{pH}$ and Lead Leachability

Table 3 shows the lead-contaminated clay (Sample J) leached out about 75\% lead in 18 -h extraction. This indicated that, lead was absorbed by clay surfaces or bound in the silicate and organic materials [8]. Additionally, it can observe that all the sample with SCB either treated or untreated has been fulfill the limit of $5 \mathrm{mg} / \mathrm{L}$ that stipulated by Kualiti Alam Sdn. Bhd [11].

\section{Conclusion}

In this study, it was observed that lead stabilization and solidification using SCB replacement is possible. However, based on TCLP and SPLP result after treatment, shows that by using treated SCB (sample G, H and I) there have a significant reduction of lead leachability up to $99.6 \%$. The optimum mix design for S/S of lead contaminated soil using both OPC and treated SCB is $7.5 \%$ OPC and $7.5 \%$ treated SCB from total weight of $160 \mathrm{~g}$ of the sample. As a conclusion, lead stabilization and solidification using OPC and SCB can be suitable procedure to immobilize lead residues in soil, if such matrices are used or kept in environments which are not exposed to an aggressive media in terms of $\mathrm{pH}$ value since leachability is proven to be very much $\mathrm{pH}$ dependent.

\section{Acknowledgement}

The authors would like to thank Universiti Tun Hussein Onn Malaysia for supporting this research. 


\section{References}

[1] H. Klee: The cement sustainability initiative. Future technologies and innovations in the cement sector in china: modeling the future cement industry, Beijing, China; 17 November 2008.

[2] V. M. Mangesh, V. R. Rahul, A. M. Sachin: Application of agro-waste for sustainable construction materials: A review. Construction and Building Materials 38 (2013) p. 872-878.

[3] S.R. Karade: Cement-bonded composites from lignocellulosic wastes, Construction and Building Materials 24 (2010) p. 1323-1330.

[4] R. Malviya and R. Chaundary: Leaching behavior and immobilization of heavy metals in solidified/stabilized products. Journal of Hazardous Materials B137 (2006) p. 207-217.

[5] H. H. Rump and H. Krist: Laboratory Manual for the Examination of Water, Waste Water and Soil. Weinheim, Verlag Chemie, (1988).

[6] U. S. Environmental Protection Agency (US EPA), Method 1311. Toxicity characteristic Leaching Procedure, SW-846: Test Methods for Evaluating Solid Waste, Physical/Chemical Methods, (1998).

[7] U.S. Environmental Protection Agency (US EPA), Method 1312. Synthetic Precipitation Leaching Procedure, SW-846: Test Methods for Evaluating Solid Waste, Physical/Chemical Methods, (1994).

[8] M.A. Janusa, C. A. Champagne, J. C. Fanguy, G. E. Heard, P.L. Laine and A.A. Landy: Solidification/stabilization of lead with the aid of bagasse as an additive to Portland cement. Microchemical Journal 65 (2000) p. 255-259.

[9] E.V. Grega and L. Domen: Efficiency modeling of solidification/stabilization of multi-metal contaminated industrial soil using cement and additives. Journal of Hazardous Materials 192 (2011) p. 753- 762.

[10] M. W. Abdel Raouf, H. G. Nowier: Assessment of Fossil Fuel Fly Ash Formulations in the Immobilization of Hazardous Wastes. Journal of Environmental Engineering 130 (2004) p. 499-507.

[11] Kualiti Alam Sdn. Bhd, Waste Management Centre, waste Evaluation Guidelines, 2005, http://www.kualitialam.com/web/services/weg.htm

[12] M.D. LaGrega, P.L. Buckingham and J.C. Evans. Hazardous Management: Mc Graw Hill Inc., New York, (2001) pp. 677-740.

[13] Y. C. Yang, Wan Shabuddin Wan Ali and L.Y. Pei, Oil palm ash as partial replacement of cement for solidification/stabilization of nickle hydroxide sludge. Journal of Hazardous Materials 150 (2008) p. 413-418. 